\title{
Microstructure and crystallographic structure of ferritic steel subjected to stress-corrosion cracking
}

\author{
V. D. Sitdikov ${ }^{\dagger}$ A. A. Nikolaev, G. V. Ivanov, A. K. Makatrov, A. V. Malinin \\ †SitdikovVD@bnipi.rosneft.ru \\ RN-BashNIPIneft, LLC, Ufa, 450076, Russia
}

\begin{abstract}
The article presents the results of studies on the microstructure and crystallographic texture of ferritic steel under stresscorrosion cracking (SCC). Using scanning electron microscopy (SEM), the size and type of non-metallic inclusions, the elemental composition of corrosion products, and the cracking mode in the SCC zone were determined. As a part of $\mathrm{X}$-ray diffraction (XRD) analysis, during which the shape and size of grains-crystallites, crystallographic texture, atomic displacements, the Debye-Waller factor and instrumental broadening of lines using the Caliotti function for LaB6 were taken into account, parameters of the microstructure in the SCC zone were assessed. It is shown that the SCC zone is characterized by high density of introduced edge-type dislocations, strong elastic microdistortions of the crystalline lattice and a relatively small size of coherent scattering domains (CSD). It is found that the processes of texture formation in the pipeline during SCC are characterized by a set of Cube $\{001\}<100>$, Brass $\{110\}<1 \overline{1} 1>$, Copper $\{112\}<\overline{1} 1 \overline{1}>$, rotated copper $\mathrm{H}\{001\}<1 \overline{1} 0>$, Goss $\{001\}<110>$ and $\mathrm{CH}\{001\}<2 \overline{1} 0>$ orientations. It is shown that when approaching the zone where there are no SCC traces, orientations of Goss $\{001\}<110>$, Copper $\{112\}<\overline{1} 1 \overline{1}>$ and Rot $G\{011\}<0 \overline{1} 1>$ type increase and orientations of Cube $\{001\}<100>, \mathrm{H}\{001\}<1 \overline{1} 0>$ and $\mathrm{CH}\{001\}<2 \overline{1} 0>$ type decrease.
\end{abstract}

Keywords: corrosion, cracking, ferritic steel, X-ray diffraction analysis, crystallographic texture.

\section{Микроструктура и кристаллографическая структура ферритной стали, подвергнутой коррозионному разрушению под нагрузкой}

\author{
Ситдиков В.Д. ${ }^{\dagger}$, Николаев А. А., Иванов Г. В., Макатров А. К., Малинин А. В. \\ ООО «РН-БашНИПИнефть», Уфа, 450076, Россия
}

В статье представлены результаты исследования микроструктуры и кристаллографической текстуры ферритной стали при коррозионном разрушении под нагрузкой (КРН). Методом растровой электронной микроскопии установлен размер и тип неметаллических включений, элементный состав продуктов коррозии, характер разрушения в зоне действия КРН. В рамках рентгеноструктурного анализа (РСА), при котором учитывали форму и размер зерен-кристаллитов, кристаллографическую текстуру, заселенность кристаллической решетки атомами, атомные смещения, фактор Дебая-Уоллера и инструментальное уширение линий с использованием функции Калиотти на LaB6, оценены параметры тонкой структуры в зоне разрушения и в свободной от КРН зоне. Показано, что область разрушения характеризуется высокой плотностью внесенных дислокаций краевого типа, сильными упругими искажениями кристаллической решетки и относительно малым размером областей когерентного рассеяния (ОКР). Установлено, что процессы текстурообразования в трубопроводе при КРН, характеризуются набором Cube $\{001\}<100>$, Brass $\{110\}<1 \overline{1} 1>$, Copper $\{112\}<\overline{1} 1 \overline{1}>$, повернутой медной Н $\{001\}<1 \overline{1} 0>$, Goss $\{001\}<110>$ и нетипичной $\mathrm{CH}\{001\}<2 \overline{1} 0>$ ориентировкой с высокой долей. Показано, что по мере приближения к области, где отсутствуют следы КРН, весовая доля таких ориентировок как Goss $\{001\}<110>$, Copper $\{112\}<\overline{1} 1 \overline{1}>$ и Rot G $\{011\}<0 \overline{1} 1>$ растут, а доли Cube $\{001\}<100>$, H $\{001\}<1 \overline{1} 0>$ и СН $\{001\}<2 \overline{1} 0>$ компонент уменьшаются. В результате сделан вывод о том, что разрушение трубопроводов по механизму КРН сопровождается не только повышенной долей Cube $\{001\}<100>$ и $\mathrm{H}\{001\}<1 \overline{1} 0>$ ориентировок, но и формированием $\mathrm{CH}\{001\}<2 \overline{1} 0>$ компоненты.

Ключевые слова: : коррозия, разрушение, ферритная сталь, рентгеноструктурный анализ, кристаллографическая текстура. 


\section{Introduction}

Nowadays, due to high strength and corrosion-resistant properties, ferritic/martensitic steels are widely used in the production of pipelines for the oil and gas industry $[1,2]$. During long-term operation, due to the interaction of steel pipelines with electrolytes and the action of a certain load on them, corrosion processes develop on the outer and inner walls, often leading to the pipeline destruction [3]. Various procedures for improvement of physical and mechanical properties of metallic materials and control of their corrosion resistance include the improvement of the crystallographic texture $[4,5]$. The crystallographic texture of the material represents preferred grain orientations to which the orientations $g\left(\varphi_{1}, \Phi, \varphi_{2}\right)$ with their characteristic weight fractions in the three-dimensional Euler angle space correspond. On the other hand, $\mathbf{g}\left(\varphi_{1}, \Phi, \varphi_{2}\right)$ is mathematically an orientation distribution function (ODF). In the case of a textured material formed as a result of thermomechanical treatment, certain texture maxima appear in the space of Euler angles, which most often form fibers with a certain set of orientations. In this case, even a slight impact on the material may lead to a redistribution of orientations in ODF. Thus, the ODF analysis makes it possible to establish the nature of preferential orientations of grains and their fraction under thermomechanical effects in the selected coordinate system. In the case of rolled specimens, such a coordinate system is represented by three-dimensional system, where the axes are oriented respectively along the rolling direction (RD), transverse direction (TD) and normal direction (ND) perpendicular to the rolling plane.

It is known that the processes of texture formation and anisotropy of mechanical properties during flat rolling of steels are significantly influenced by the content of alloying elements such as $\mathrm{C}, \mathrm{Si}$, and Cr. [6,7]. Depending on the content of alloying elements $\mathrm{C}, \mathrm{Si}$, and $\mathrm{Cr}$, either austenitic (fcc - face centered cubic) or martensitic (bcc - body centered cubic, ferrite) phase predominates in steels, and the texture formation processes in these phases significantly differ during thermomechanical treatment. In particular, during the rolling of martensitic steel, the crystallographic texture is characterized by a set of $\alpha_{\mathrm{bcc}}, \gamma, \eta, \zeta$, and $\varepsilon$ fibers, and in the case of the austenitic phase - by $\alpha_{\mathrm{fcc}}$ and $\beta$ fibers containing another set of $\mathrm{g}\left(\varphi_{1}, \Phi, \varphi_{2}\right)$ orientations in the Euler angles space [6-8]. In particular, when rolling the austenitic steel these fibers contain Cube $\{001\}<100>$, Brass $\{011\}<211>$, Copper $\{112\}<111>$, S $\{123\}<634>$ and Goss $\{011\}<100>$ orientations. In case of ferritic steel, $\alpha_{\text {bcc }} \gamma, \eta$, $\zeta$ and $\varepsilon$ fibers contain Cube $\{001\}<100>$, Brass $\{110\}<1 \overline{1} 1>$, Copper $\{112\}<\overline{1} 1 \overline{1}>, H\{001\}<1 \overline{1} 0>$, Goss $\{001\}<110>$ and set of $\{112\}<1 \overline{1} 0>,\{111\}<1 \overline{1} 0>,\{111\}<1 \overline{2} 1>$ and $\{111\}<0 \overline{1} 1>$ textural component [6-9]. At the same time, the formation of certain orientations and their stability are strongly influenced by the conditions of rolling (temperature, reduction degree) and operating modes [6-9]. In particular, during operation [10] as a result of the analysis of preferred orientations, it was found that the inhomogeneous distribution of the crystallographic texture in ferritic steel over the thickness of the pipe leads to an increase in the SCC resistance. At the same time, the authors of [10] noted that the presence of the
$\{011\}<100>$ orientation in the outer layers of pipes increases their resistance to SCC, and the high value of orientations in abcc fiber reduces the resistance to SCC.

In the case of corrosion destruction of steel pipelines, it is relevant to establish the mechanisms and causes of this destruction. Thus, this work analyzes the microstructure and crystallographic texture, which allow one to establish the basic patterns of the destruction process of steel pipelines by the SCC mechanism. The X-ray scattering method comparatively analyzed the fine structure parameters and the predominant orientation of the grains in the SCC area and in the SCC free area. By qualitative and quantitative comparison of preferential orientations, those of them that are characteristic only for the SCC were established. The identification and establishment of quantitative ratios of orientations characteristic of the area subjected to SCC will further allow establishing the destruction by the SCC mechanism in other pipelines.

\section{Material and methods of studies}

Section of steel pipeline of GS-09F grade (wt.\%: C $\leq 0.12$, $\mathrm{Si} \leq 0.5-0.8, \quad \mathrm{Mn} \leq 1.3-1.7, \quad \mathrm{Ni} \leq 0.3, \quad \mathrm{~S} \leq 0.04, \quad \mathrm{P} \leq 0.035$, $\mathrm{Cr} \leq 0.3, \mathrm{~N} \leq 0.012, \mathrm{Cu} \leq 0.3)$ was selected as the material for the study. The pipeline was subjected to stress-corrosion cracking at the pumping station. For research purposes, four arcuate specimens $4 \mathrm{~mm}$ wide and $40 \mathrm{~mm}$ long were cut from a $6 \mathrm{~mm}$ thick pipeline cross section. Since the macrocrack caused by SCC was located parallel to the pipe axis, one side of the cut specimens covered the area of SCC action, and the other side corresponded to the SCC-free zone. Before the study, the samples were ground and polished using diamond paste. All studies were performed for the central region (SSC, SSC free) of the pipeline cross section.

$\mathrm{X}$-ray diffraction analysis was carried out using a Rigaku Ultima IV diffractometer with a Bragg-Brentano goniometer configuration using monochromated copper radiation $(U=40 \mathrm{kV}, I=40 \mathrm{~mA})$. During the survey using X-ray patterns from $20^{\circ}$ to $147^{\circ}$ continuous scanning mode with a speed of $1 \mathrm{deg}$./min was used. PM2K program was used for calculation of the lattice parameter, distribution of grainscrystallites by sizes, density of edge and screw dislocations [11]. During the calculation of X-ray patterns, such parameters as the sample plane (zero angle) displacement, lattice parameter $a$, dislocations density $\rho$, volume fraction of edge dislocations $m_{\mathrm{ixp}}$, effective radius $R_{\mathrm{e}}$ of dislocations and size $D$ of the grains-crystallites were varied. The shape of grains-crystallites during modeling was set in the form of a sphere with a lognormal size distribution [11], since they are close to equiaxed according to SEM studies (Fig. 1). The X-ray patterns were calculated as a result of at least 40 iterations with initial parameters equal to: $\rho=1.0 \cdot 10^{12} \mathrm{~m}^{-2}$, $m_{\mathrm{ixp}}=0.5, \quad R_{\mathrm{e}}=3.0 \mathrm{~nm}$. Cagliotti function parameters (instrumental broadening), defined as a result of the X-ray pattern analysis from $\mathrm{LaB}_{6}$, were equal to $W=1.93 \cdot 10^{-3} \mathrm{rad}^{2}$, $V=6.27 \cdot 10^{-4} \mathrm{rad}^{2}, \quad U=2.03 \cdot 10^{-3} \mathrm{rad}^{2}, a=2.38 \cdot 10^{-1} \mathrm{~nm}$, $b=9.93 \cdot 10^{-3} \mathrm{~nm}, c=0 \mathrm{~nm}$. When calculating an averaged contrast factor, $A_{\mathrm{e}}=0.2653, B_{\mathrm{e}}=-0.3559$ ratios were used for edge dislocations, and $A_{\mathrm{s}}=0.3073, B_{\mathrm{s}}=-0.8200-$ for screw dislocations. 


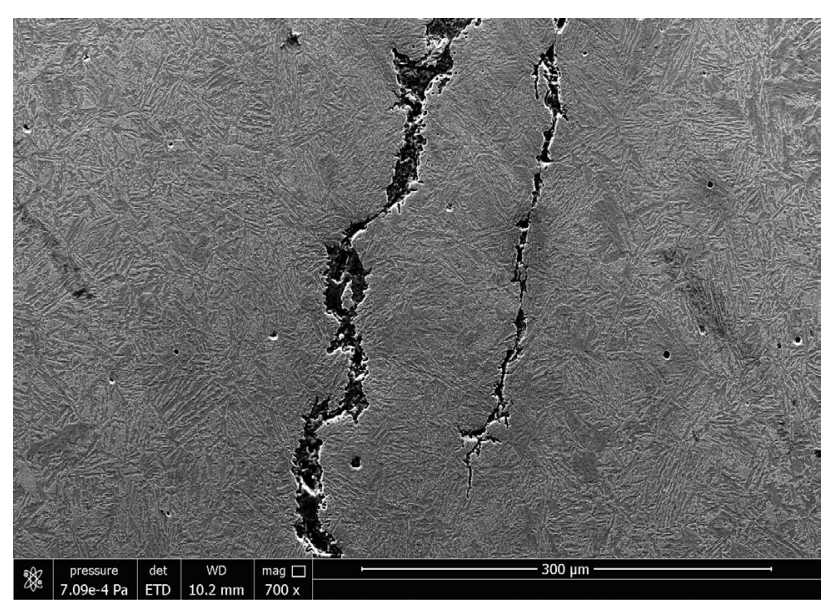

a

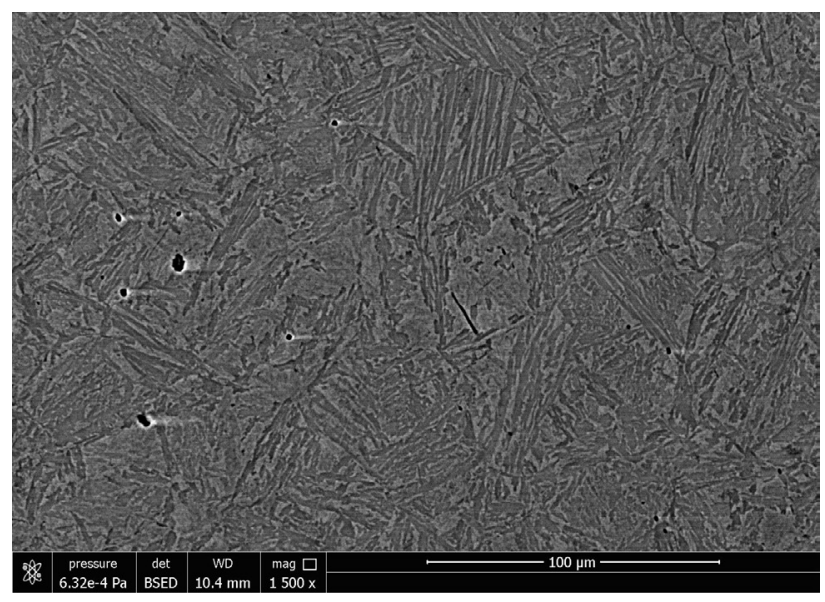

c

Fig. 1. SEM images of steel: SCC zone $(a, b)$ and SCC free area $(c, d)$.

To carry out the texture analysis, the measurements of incomplete pole figures (PF) were carried out in "on reflection" mode within the range of changes in the radial angle $\gamma$ from $0^{\circ}$ to $75^{\circ}$ and the azimuth angle $\delta$ from $0^{\circ}$ to $360^{\circ}$. Incomplete PF were measured using the Rigaku Ultima IV diffractometer equipped with an automatic texture adapter on parallel ray. When scanning incomplete $\mathrm{PF}, \mathrm{Cu} \mathrm{Ka}{ }_{1} \mathrm{X}$-radiation filtered on secondary beam, was used. ODF has been built as a result of incomplete PF obtained for reflections (111), (200) and (220). Results of experimental texture analysis were presented in the form of complete PF and ODF obtained in the LaboTEX program (ver. 3.1).

Ferritic steel microstructure was studied on the Thermo Scientific Q250 scanning electron microscope, manufactured by FEI. Main properties of scanning the samples under study: accelerating voltage is $30 \mathrm{kV}$; beam diameter is $3 \mu \mathrm{m}$, focal distance is $9.5-11 \mathrm{~mm}$, pressure is $10^{-4}-10^{-2} \mathrm{~Pa}$.

\section{Results of experimental studies}

The microstructure of a steel pipe subjected to SCC in the cross-section is shown in Fig. 1a, b. Multiple microcracks with a length of up to $500 \mu \mathrm{m}$ visible in the SCC zone. Analysis of multiple SEM images at the fracture boundary showed that coverage of the corrosion processes propagation is extended

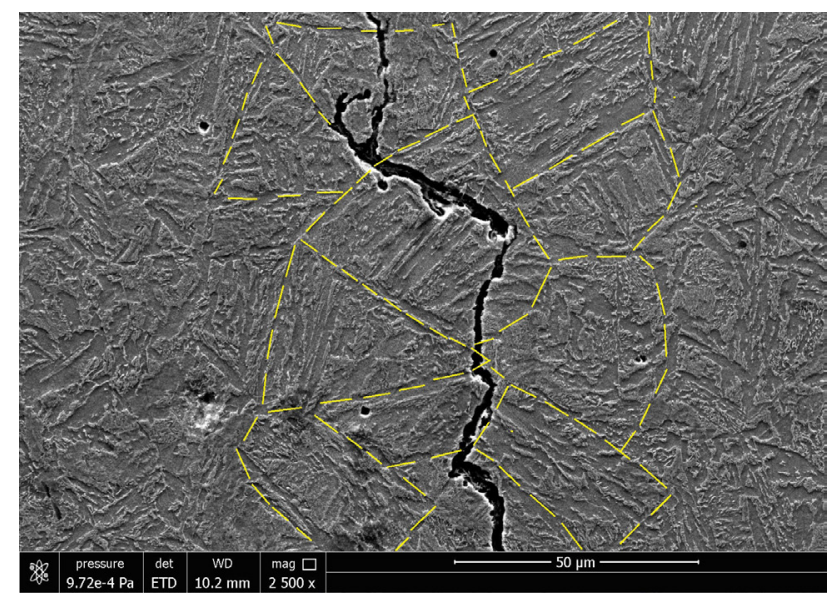

b

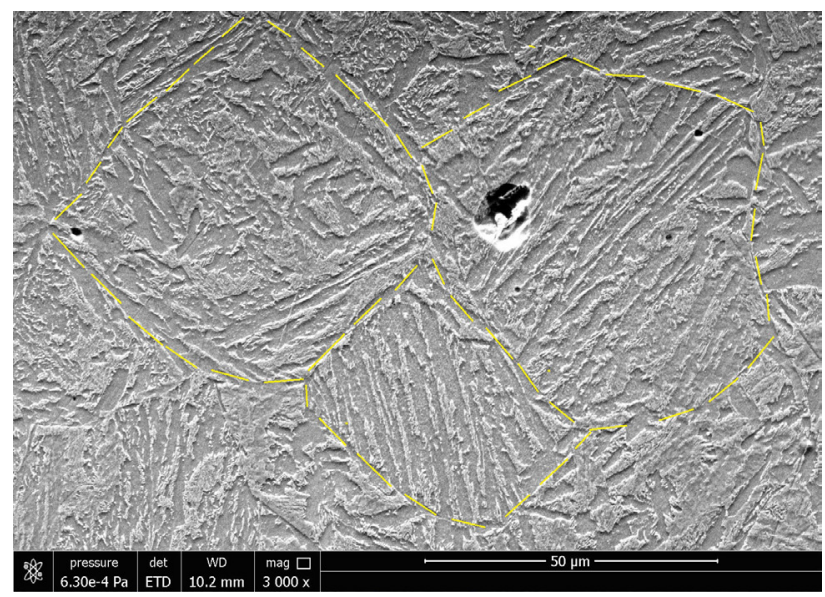

d

and mainly has uneven zones with multiple secondary cracks. The maximum depth of corrosion crackings in the pipe amounted to more than $800 \mu \mathrm{m}$. The nature of cracking and the type of the microcracks propagation are indicative of the transcrystalline type of SCC (Fig. 1a,b).

The microstructure of the SCC-free zone is characterized by a homogeneous ferrite-martensite structure with an average grain size of $35 \mu \mathrm{m}$ (Fig. 1c, d). In addition, Fig. 1c, d shows multiple defects of predominantly spherical in shape, isolated from each other, which belong to non-metallic inclusions of different diameters (2 to $10 \mu \mathrm{m}$ ). Such defects are also typical for zone covered with SCC (Fig. 1a,b). EDS analysis in the corrosion zone detected the presence of such elements as $\mathrm{C}, \mathrm{O}, \mathrm{Si}, \mathrm{Ca}, \mathrm{Cl}$ and $\mathrm{Fe}$ that may generate oxides (magnetite, hematite, akaganeite, lepidocrocite) and carbonates (siderite) of iron as well as calcite and quartz.

Fig. 2 shows the diffraction patterns of steel measured in the cracking zone and in the free zone separated from the cracking zone to a sufficiently large distance. The diffraction patterns are characterized by a set of reflections with Miller indices (110), (200), (211), (220), (310) and (222), typical for metals with bcc lattice. At the same time, they vary in terms of different reflections intensities, which are directly related to the formation of different crystallographic textures in the samples. In particular, the relative intensity of such diffraction 
peaks as (200), (211) and (310) is rather low in the SCC-free zone (Fig. 2, Table 1).

To define the steel microstructure parameters, diffraction patterns were simulated using the PM2K program. Experimental and simulated diffraction patterns of steel are shown in Fig. 2 as dots and solid black lines, respectively. Difference curves (blue lines) between the experimental and simulated diffraction patterns is also shown here. At the same time, $R_{\mathrm{wp}}$ factor reflecting difference degree of the diffraction patterns (the lower, the more accurate) was $8.7 \%$ for the upper diffraction pattern and $9.6 \%$ for the lower one. This indicates a high extent of the experiment and simulation matching. Data on parameters of the fine steel structure for considered zones of steel pipeline found as a result of processing the XRD diffraction patterns are given in Table 2.

To establish the effect of SCC on the crystallographic texture, we analyzed the preferred orientations in steel in the cracking zone and in the zone free from SCC. The experimental ODF in the sections $\varphi_{1}=0^{\circ}$ and $\varphi_{2}=45^{\circ}$ (typical sections in which main ideal orientations are revealed) corresponding to the studied conditions as well as positions of ideal orientations are shown in Fig. 3a-d. The ODF sections under study usually show all typical ideal orientations of the bcc metals (Fig. 3 e, f).

The positions of certain ideal orientations, expressed in Euler angles, as well as their volume fractions calculated within the area bounded by the angles $\Delta \varphi_{1}=\Delta \varphi_{2}=\Delta \Phi \leq 10^{\circ}$ are also given in Table 3. The analysis of ODF showed that main orientations in pipeline steel, both in the SCC zone and in the free zone, are orientations of Cube, Goss, Brass, Copper, $\mathrm{H}$ and Rot $\mathrm{G}$ type (Fig. 3). Besides, formation of the $\mathrm{CH}$ orientation with high volume fraction (Fig. 3, Table 3) was detected in the SCC affected area.

\section{Discussion}

Studies of the steel pipeline, carried out by XRD methods, allowed establishing the influence of SCC on its microstructure and crystallographic texture. In particular, a full-profile analysis of steel diffraction patterns showed that the cracking zone on the one hand, is characterized by increased intensities of certain reflections, and, on the other hand, by a broadening of the maxima (Table 1). This is indicative of grain crushing and an increase in the accumulated density of defects introduced as a result of SCC. Lattice parameter assessment shows that its value amounts

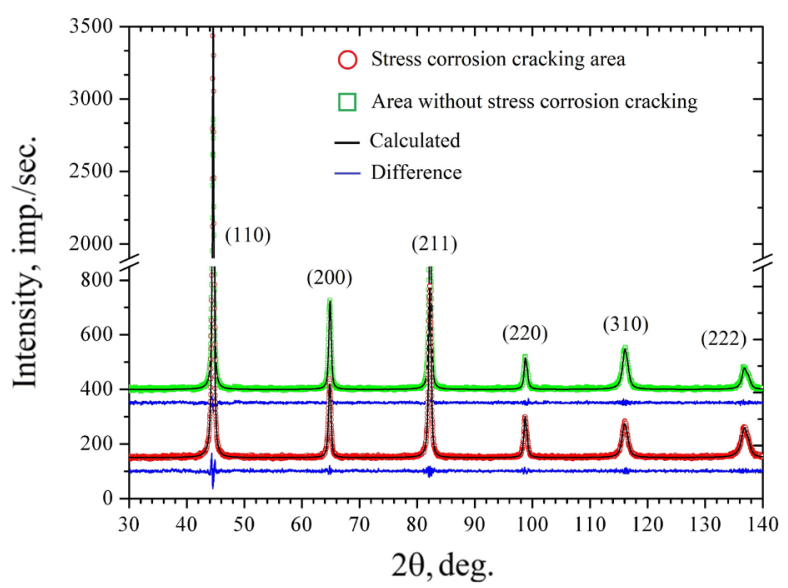

Fig. 2. (Color online) Steel X-ray patterns obtained in the area subjected to SCC and in the SCC free area.

to $0.287016(6) \mathrm{nm}$ (Table 2) for the SCC zone. This value significantly differs from such a value, typical for tabular data of ferritic steel $(0.28660 \mathrm{~nm})$ [12]. This difference, apparently, is due to the presence of impurity interstitial/substitutional atoms in the crystalline lattice of steel as a result of SCC, high extent of distortion in the crystalline lattice and the presence of residual macrostresses. Analysis of the types of dislocations showed that in the SCC area they mainly belong to the edge type, since the $m_{\mathrm{ixp}}$ parameter is closer to $100 \%$ (Table 2). However, the density of dislocations amounted to $4.2 \cdot 10^{-14} \mathrm{~m}^{-2}$. When moving closer to the zone where there are not SCC traces, the size of CSD increases, microdistortions $\varepsilon$ of the crystalline lattice and dislocations density $\rho$ decrease (Table 2). The lattice parameter also decreases when moving closer to the SCC-free zone. This is indicative of a relatively small contents of impurities in the SCC-free zone. Besides, dislocations are mainly of the screw type in the free zone since the $m_{\mathrm{ixp}}$ parameter is close to zero (Table 2). The average density of dislocations in the SCC-free area decreases by a factor of more than two.

For a quantitative comparative analysis of the texture formation processes in steel with SCC, a quantity called texture index $T=\int[f(g)]^{2}$ was also used. It characterizes the sharpness and overall intensity of the textural maxima. Calculations have shown that the texture index in the SCC zone is 1.6 times less than that typical for the free zone. This suggests that SCC processes result in spread of texture maxima. An analysis of the texture formation processes showed that main orientations in pipeline steel both, in the

Table 1. Distribution of relative intensities $I$ and diffraction lines broadening at half maximum (FWHM) of steel in different zones.

\begin{tabular}{|c|c|c|c|c|c|c|c|}
\hline \multicolumn{2}{|c|}{ Condition } & $(110)$ & $(200)$ & $(211)$ & $(220)$ & $(310)$ & $(222)$ \\
\hline \multirow{2}{*}{ SCC zone } & $I$, unit. & 100.00 & 10.35 & 23.45 & 3.85 & 5.29 & 4.61 \\
\cline { 2 - 9 } & FWHM, deg. & 0.229 & 0.441 & 0.438 & 0.507 & 0.878 & 0.973 \\
\hline \multirow{2}{*}{ SCC free zone } & $I$, unit. & 100.00 & 7.11 & 20.03 & 4.33 & 4.06 & 3.89 \\
\cline { 2 - 9 } & FWHM, deg. & 0.252 & 0.434 & 0.429 & 0.501 & 0.791 & 0.945 \\
\hline
\end{tabular}

Table 2. Steel microstructure parameters in various structural conditions. Parentheses contain measurement errors related to the last significant digits.

\begin{tabular}{|c|c|c|c|c|c|}
\hline Condition & $a, \mathrm{~nm}$ & $D, \mathrm{~nm}$ & $\varepsilon, \%$ & $\rho, 10^{14} \mathrm{~m}^{-2}$ & $m_{\mathrm{ixp}} \%$ \\
\hline SCC area & $0.287016(6)$ & $450(70)$ & $0.293(8)$ & $4.2(2)$ & 73 \\
\hline SCC free area & $0.286879(9)$ & $806(91)$ & $0.261(7)$ & $1.8(1)$ & 37 \\
\hline
\end{tabular}




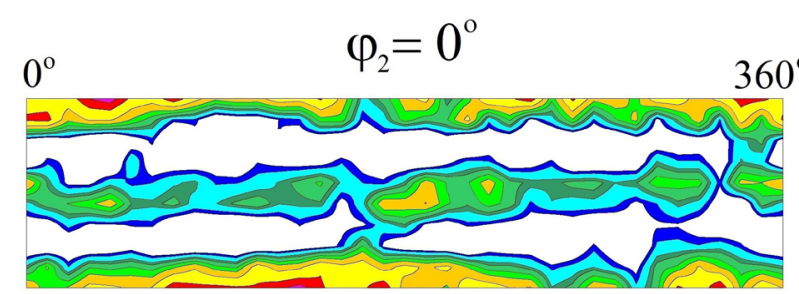

$90^{\circ}$

a

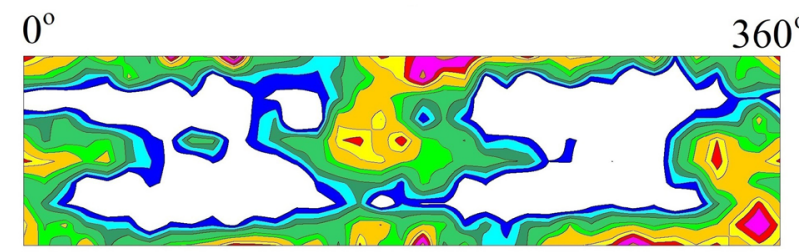

$90^{\circ}$

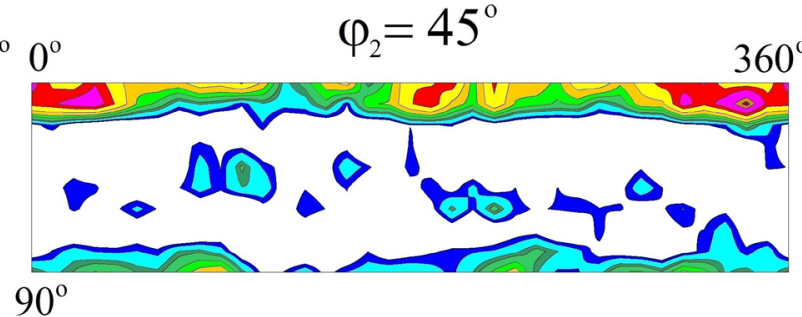

$\mathrm{b}$

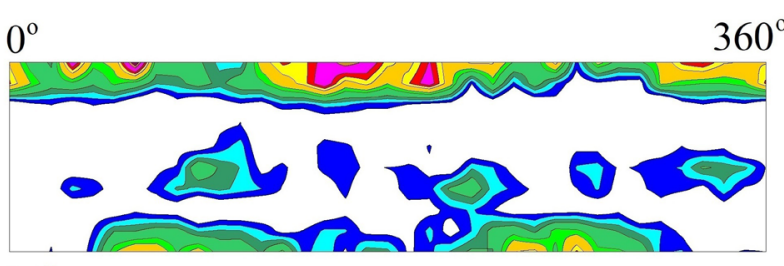

$90^{\circ}$

d

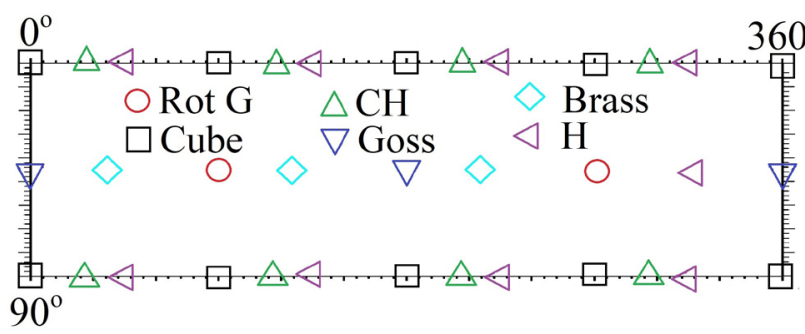

e

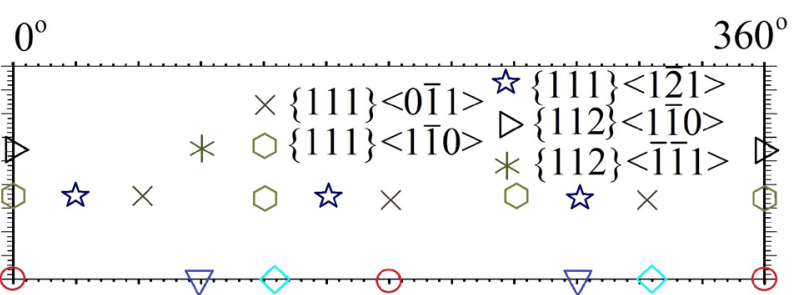

$\mathrm{f}$

Fig. 3. (Color online) $\varphi_{2}=0^{\circ}$ and $\varphi_{2}=45^{\circ}$ sections of orientations in the Euler space for area affected by SCC (a, b) and in the SCC free area $(c, d)$, positions of ideal orientations $(e, f)$.

Table 3. Euler angles for ideal bcc metal orientations at flat rolling and their corresponding volume fractions.

\begin{tabular}{|c|c|c|c|}
\hline \multirow{2}{*}{ Main orientations } & \multirow{2}{*}{ Euler angles, $\left\{\varphi_{1}, \Phi, \varphi_{2}\right\}$} & \multicolumn{2}{|c|}{ Volume fraction, $\%$} \\
\hline & & SCC zone & SCC free zone \\
\hline Cube $\{001\}<100>$ & $\begin{array}{l}\{0 / 90 / 180 / 270 / 360,0,0\} \\
\{0 / 90 / 180 / 270 / 360,90,0\}\end{array}$ & 16.24 & 10.33 \\
\hline Goss $\{001\}<110>$ & $\begin{array}{c}0 / 180 / 360,45,0\} \\
\{90 / 180 / 270,90,45\}\end{array}$ & 4.51 & 7.22 \\
\hline Brass $\{110\}<1 \overline{1} 1>$ & $\begin{array}{l}\{35.26 / 215.26,90,45\}, \\
\{125.26 / 305.26,90,45\}\end{array}$ & 3.86 & 4.05 \\
\hline Copper $\{112\}<\overline{1} 1 \overline{1}>$ & $\{90,35.26,45\}$ & 2.20 & 3.67 \\
\hline $\mathrm{H}\{001\}<1 \overline{1} 0>$ & $\begin{array}{l}\{45 / 135 / 225 / 315,0,0\} \\
\{45 / 135 / 225 / 315,90,0\}\end{array}$ & 8.92 & 5.19 \\
\hline $\operatorname{Rot} G\{011\}<0 \overline{1} 1>$ & $\begin{array}{c}\{90 / 270,45,0\} \\
\{180 / 360,90,45\}\end{array}$ & 2.78 & 4.28 \\
\hline $\mathrm{CH}\{001\}<2 \overline{1} 0>$ & $\begin{array}{l}\{26.57 / 116.57 / 206.57 / 296.57,0,0\}, \\
\{26.57 / 116.57 / 206.57 / 296.57,90,0\}\end{array}$ & 10.73 & 2.09 \\
\hline
\end{tabular}

SCC zone and in the free zone are orientations of Cube, Goss, Brass, Copper, $\mathrm{H}$ and Rot G type (Fig. 3, Table 3), which are typical for metals with bcc. At the same time, $\mathrm{CH}$ orientations were detected that are typical for the SCC zone only (Fig. $3 \mathrm{a}, \mathrm{b}$, Table 3). When moving closer to the SCC-free zone, volume fractions of Goss, Copper, Rot $\mathrm{G}$ orientations go up, fractions of Cube, $\mathrm{H}$ and $\mathrm{CH}$ component go down while Brass orientation remains stable (Fig. 3, Table 3). In particular, in the SCC zone, the fraction of Cube orientation is more than
1.5 times higher, $\mathrm{H}$ orientations are more than 1.7 times higher while $\mathrm{CH}$ orientations are more than 5 times higher than similar fractions of orientations typical for free zone. This fact indicates that the processes of texture formation in the SCC area are much more intense, in other words, a larger number of grains are subjected to rotations, according to the applied flow stresses.

The redistribution of the volume fractions of orientations when moving from the SCC zone to the free zone is directly 
related to changes in the microstructure of steel. In particular, a relatively small fraction of $\mathrm{H}$ components in the free zone indicates, on the one hand, that grains with $\{001\}<110>$ orientation are intensively absorbed by neighboring grains and, on the other hand, new boundaries emerge in them reorienting the grain [9]. Goss and Brass orientations are usually formed during the generation of shear bands resulted by shear deformation modes when forming the pipeline [7]. A relatively small fraction of Goss and Brass orientations in the SCC zone reflects a weak resistance of shear bands to the corrosion process. The high volume fraction of Cube and $\mathrm{H}$ orientations in the SCC zone is indicative of recovery and recrystallization processes in steel where not only growth of equiaxed grains, but softening of steel take place [7].

\section{Conclusions}

Experimental studies of the microstructure and processes of forming the crystallographic texture of steel subjected to SCC indicate that the sections of pipelines affected by SCC are characterized by an increased lattice parameter, a relatively small size of grains-crystallites, an increased value of elastic microdistortions of the crystalline lattice, a high density of dislocations having mainly edge character. The processes of texture formation in pipeline steel in the cracking area are characterized by the formation of a flat rolling texture, on which the texture formed as a result of SCC is superimposed. A relatively high volume fraction of Cube, $\mathrm{H}$ and $\mathrm{CH}$ orientations may be indicative of steel pipelines cracking due to the SCC mechanism.

Acknowledgments. The authors are grateful to OJSC Rosneft Oil Company and RN-BashNIPIneft LLC for the opportunity to conduct the research and publish this paper. The authors also thank Senior Expert A. I. Voloshin (RN-BashNIPIneft LLC) for the discussion of the obtained results and valuable comments.

\section{References}

1. A. Bahadori. Oil and Gas Pipelines and Piping Systems: Design, Construction, Management, and Inspection. Elsevier Science (2016) 660 p. Crossref

2. T. Hara, H. Semba, H. Amaya. Pipe and Tube Steels for Oil and Gas Industry and Thermal Power Plant. Elsevier, Amsterdam, The Netherlands (2020).

3. M.S. Okyere. Corrosion Protection for the Oil and Gas Industry: Pipelines, Subsea Equipment, and Structures. CRC Press (2019) 186 p. Crossref

4. B.S. Ermakov, A.A. Alhimenko, N.O. Shaposhnikov, A.S. Tsvetkov, A.V. Shirokov. Lett. Mater. 10 (1), 48 (2020). (in Russian) [Б. С. Ермаков, А. А. Альхименко, Н.О. Шапошников, А.С. Цветков, А.В. Широков. Письма о материалах. 10 (1), 48 (2020).] Crossref

5. S. Chatterjee, S. Koley, S. D. Bakshi, M. Shome. Mater. Sci. Eng. A. 708, 254 (2017). Crossref

6. D. Raabe, K. Lüucke. Mater. Sci. Technol. 9, 302 (1993). Crossref

7. D. Raabe. Steel research International. 74, 327 (2003). Crossref

8. D. Raabe, K. Lucke. Mater. Sci. Forum. 157, 597 (1994). Crossref

9. M. Holscher, D. Raabe, K. Lucke. Steel Res. Int. 62, 567 (1991). $\underline{\text { Crossref }}$

10. O.A. Krymskaya, Yu.A. Perlovich, N.S. Morozov, V.A. Fesenko, M.G. Isaenkova, I. V. Ryakhovskikh, T.S. Yesiev. Territoryofneftegaz.2(31), 48(2015).(in Russian) [О.А. Крымская, Ю.А. Перлович, Н.С. Морозов, В.А. Фесенко, М.Г. Исаенкова, И.В. Ряховских, Т. С. Есиев. Территория нефтегаз. 2 (31), 48 (2015).]

11. M. Leoni, T. Confente, P. Scardi. Z. Kristallogr. Suppl. 23, 249 (2006). Crossref

12. H. E. Swanson, E. Tatge. Natl. Bur. Stand. (U. S.). Circ. 539 IV, 3 (1955). 